\title{
FROM THE GREAT UNION OF 1918 TO THE STRATEGIC PARTNERSHIP: A CENTURY OF U. S. - ROMANIA RELATIONS
}

George Cristian Maior

SNSPA, Romania, email: george.maior@mae.ro

\begin{abstract}
The article argues that the US-Romania Strategic Partnership is the logical and mutually advantageous result of the two countries' shared values and core interests, evidenced by the evolution of bilateral relations over the past century. To that end, the analysis focuses on four main aspects: (1) the historical dimension, in particular US support for Romania's Great Union and the role of the Romanian-American community in that context, (2) the common values and strategic vision of the two countries in the post-1989 period; (3) the current state and substance of the Partnership and (4) its potential and future perspectives. The conclusions show that the US-Romania Strategic Partnership is based upon shared long-term strategic interests, a common set of values, as well as genuine affinity and friendship between the two peoples. These aspects are validated by a history of constructive engagement and cooperation. The value of the Strategic Partnership is proven by its concrete results and by the fact that it is a "living" framework, continuously evolving and expanding, underscoring the bilateral compatibility and mutual benefits for both the US and Romania.
\end{abstract}

Keywords: History, Interdisciplinary Sciences, US-Romania, partnership, values, interests, compatibility, diplomacy

\section{Introduction}

The Centennial anniversary of the 1918 Great Union holds particular significance for the history of Romanian-American relations. The American contribution to the unification of Romanians in a single state is rarely and insufficiently debated in history studies. Rectifying this situation offers an opportunity to study the origins of Romania's most important strategic partnership today, the one it has with the United States of America. Examining the events of 1918 reveals a remarkable degree of historical foresight and continuity, a common thread, composed of rational geopolitical calculations, shared values and people-to-people relations, connecting the two countries across a complicated century.

The American contribution to the emergence of today's Romania is most prominently revealed by President Woodrow Wilson's vision on restoring peace in Europe at the end of the First World War. The 14 Points, presented in the joint session of the
U.S. Congress on January 8, 1918 [1] paved the way for Romania's Great Union. December $1^{\text {st }}$, Romania's National Day, is thus also a landmark for the RomanianAmerican relationship. As we celebrate it, we should also remember how American support, based on President Wilson's commitment to the principles of freedom and selfdetermination, contributed to the Great Union of Romanians and the completion of the modern Romanian state.

In this context, Romanian historiography must recover the genuinely exceptional contribution, both in 1918 and afterward, of the representatives of the RomanianAmerican community in strengthening the ties between the two countries, with obvious benefits on both sides. A century of Romanian-American relations captures both sublime and dramatic moments, seemingly always dominated by a positive constant that began in 1918. This could be seen even during the communist regime, a fact highlighted by the two visits made by 
American presidents in Bucharest in this period. After 1989, the international context allowed the bilateral relationship to achieve its genuine potential. In 2018, a century after the Great Union, the two countries have a robust strategic partner-ship, anchored in a favorable public percep-tion that makes Romania, at this time, probably the most pro-American country in Europe.

\section{Bilateral diplomatic relations during the First World War; American support for Romanians' self- determination and unity}

Romania and the United States established diplomatic relations in 1880, following Romania's declared independence in 1877. During the First World War RomanianAmerican diplomatic contacts became significant after 1917 when the U.S. entered the war. The political and military disaster caused by the chaos of the Russian Revolution had left Romania in a desperate situation, even after several seemingly impossible victories against enemy forces. For this reason, Romanian political elites regarded America's entry into the war as a timely salvation (apparently with some exaggerated interpretations, as noted by renowned American historian Victor Mamatey). However, it should be noted that the first noteworthy political signal given by the U.S. to Romania occurred on July $3^{\text {rd }}, 1917$, when U.S. Army Chief of Staff, General Hugh L. Scott, addressed the Romanian Parliament in Iasi. On that occasion, ,he assured the Rumanians [...] that the United States would fight to the end of the conflict at their side and the side of their Allies" [2]. Even though the American general's speech did not represent an explicit commitment to support Romania's political goals, the United States' entry into the war prompted a strong mobilization from the Iasi government. This mobilization included: direct appeals made by King Ferdinand, an exchange of letters with President Wilson, the appointment of the first Romanian diplomatic representative to Washington D.C., as well as actions aimed to stimulate and support the RomanianAmerican communities. Dr. Constantin Angelescu was appointed Envoy Extra- ordinary and Minister Plenipotentiary of Romania to Washington D.C. (October $1^{\text {st }}$, 1917 - March 25 ${ }^{\text {th }}$, 1918). With strong support from French diplomatic representtatives in Washington D.C., Dr. Angelescu who had arrived in the American capital only at the beginning of 1918 - presented his letters of credence to President Wilson on January 15, 1918. He sought to attract America's support in the difficult context marked by the catastrophic military consequences of the Bolshevik Revolution. Supporting Romania's political objectives, especially the union of Transylvania with the Kingdom of Romania, was the primary mission of the Romanian envoy.

One of President Wilson's personal messages addressed to the King of Romania, Ferdinand I, in November 1917, formulated the bases of American policy towards Romania: "I wish to assure Your Majesty that the United States will support Romania after the war to the best of its ability and that, in any final negotiations for peace, it will use its constant efforts to see to it that the integrity of Romania as a free and independent nation is adequately safeguarded" [3]. Along with Woodrow Wilson's assertion of the principle of nations' self-determination in the 14 Points presented before the U.S. Congress, these positions of support were used consistently, during 1918 and afterward, in the effort to unify Romania.

It is worth noting that the spirit of the 14 Points also marked the U.S. position on the unification of Bessarabia with Romania. Thus, in the suggested response sent by State Secretary Robert Lansing to President Wilson, he ,proposed to inform the Rumanian government that the United States would confirm definitely any agreement reached in accordance with the will of different peoples" [4] - which represented a de facto recognition of the union vote approved by the National Council of Bessarabia. Even though this message was not officially transmitted at that time, it reflected the U.S. authorities' willingness to support the claims of those populations unwillingly incorporated in oppressive multinational empires. American support for Romania's national unity was fully confirmed in November 1918 through a 
public declaration approved by President Wilson at a cabinet meeting: "The government of the United States is not unmindful of the aspiration of the Romanian people, without as well as within the boundaries of the Kingdom. It has witnessed their struggles and sufferings and sacrifices in the cause of freedom from their enemies and their oppressors. With the spirit of national unity and the aspirations of the Romanians everywhere the government of the United States deeply sympathizes and will not neglect at the proper time to exert its influence that the just political and territorial rights of the Romanian people may be obtained and made secure from all foreign aggression" [5]. Beside the declarations of support, it is worth mentioning the U.S. financial assistance for the Kingdom of Romania, namely granting in October 1917 a several million dollars loan to support Romania's war effort.

\section{The Romanian-Americans' contri- bution}

In addition to the official diplomatic actions, Romania's interests were strongly supported by the Romanian-American communities in the U.S., most of them originating from Transylvania. Since the beginning of the war, Americans of Romanian, Slovak, Czech, Serbian or Polish descent, namely the emigrants belonging to nations that were part of Austria-Hungary, mobilized and coordinated their effort to support the liberation of their nations from the domination of the dual monarchy [6]. Their actions intensified after America's entry into war. In May 1917, with the approval of the Romanian Government, holding letters of introduction from the U.S. diplomatic representative in the Kingdom of Romania, and enjoying French diplomatic support, Transylvanian refugees, the Greek-Catholic priest Vasile Lucaciu and lieutenant Vasile Stoica, left Iasi to the United States on a complicated route passing through Russia, Siberia and Japan. The objective of this unofficial Transylvanian mission was obvious: to encourage Romanian-Americans' actions in favor of national unity and to attract official U.S. support in this regard. The Romanian mission's first meeting took place on July 2, 1917, at the Department of State, where Secretary of State Robert Lansing received them. A few days later, they had another meeting at the Department of War with Secretary Newton D. Baker [7]. After the arrival of Thomas Masaryk, the future President of Czechoslovakia, in the U.S. in May 1918, the representatives of oppressed Austro-Hungarian nations increasingly coordinated their efforts. In this context, Vasile Stoica (now already a captain) became not just one of the most active representatives of the Romanians, but also of the other aligned nations.

Stoica and Father Lucaciu coordinated the establishment of the National League of Romanians in America, an organization that united all Romanian associations in the U.S. On May 13, 1918, in Cleveland, under the leadership of Dionisie Moldovan, the two previous associations of Romanians, called The Union, respectively, The League and Aid united and formed a unified organization. Later, on June $5^{\text {th }}, 1918$, the delegations of more than 150 organizations of Romanians in the U.S. attended the Congress of the Romanian National League and elected Vasile Stoica as president of the League [8].

From this position, captain Stoica became even more active in supporting the unification aspirations of the Transylvanian Romanians. He sent memos to President Wilson and other U.S. officials, such as Secretary of Interior, Franklin Lane, met with members of Congress and had public appearances publicized in major U.S. newspapers from New York, Washington D.C., Cleveland or Philadelphia. Via frequent contacts at the Department of State and the Department of War, he promoted the project of the Romanian Legion, designed to mobilize American-Romanians who wanted to fight on the European front. Stoica's efforts also mobilized the RomanianAmerican com-munity, who sent hundreds of letters to the White House asking support for the freedom of the Romanians and their right to be united in one state [9].

On September 20, 1918, as a member of the Committee representing the oppressed peoples of Austria-Hungary, Vasile Stoica was received by President Woodrow Wilson along with Thomas G. Masaryk, Ignace 
Paderewski, and Hinko Hinkovich. The delegates handed the U.S. President a resolution containing the wishes of the oppressed nations in Austro-Hungary, strongly supported by U.S. citizens originating in these regions. In essence, the resolution called for the dissolution of the Austro-Hungarian Empire and the organization of the liberated nations according to their own desires [10]. This collaboration led, on October 3, 1918, to the establishment of the "Mid-European Union" or "Central European Democratic Union" a U.S.-based organization bringing together Americans of Romanian, Czechoslovak, Yugoslav, Polish, as well as Italian, Lithuanian and Ruthenian origin. Vasile Stoica was elected vice-president of the organization. The most important event organized by the Union was the Great Assembly held at Philadelphia, the cradle of American independence and a symbol of freedom, between 23 and 26 October 1918. On that occasion, the Great Assembly adopted the proclamation of Independence of the oppressed nations of Austria-Hungary. The event brought together thousands of people from all over America (Fig. 1). One of the original copies of the Declaration of the Great Assembly (fig. 2) is still kept today at Independence Hall in Philadelphia.

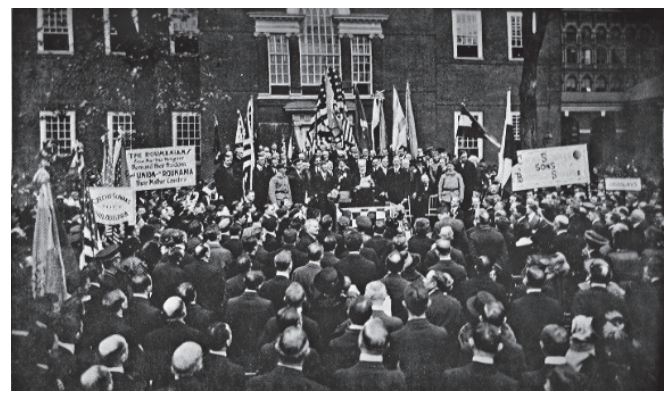

Figure 1. Delegates at the Central European Democratic Union Assembly, October 26, 1918, in Philadelphia

At the Great Assembly of Philadelphia, captain Stoica eloquently expressed the will of Romanians from the Austro-Hungarian Empire (Transylvania, Banat, and Bucovina) to unite with Romania. In response to this strong mobilization, given that the vast majority of participants had American citizenship, President Wilson sent a clear message of support, which gave substance to U.S. policy favoring self-determination and, in the case of Romanians, their unity in one state: "Please send my best wishes to the representatives of the oppressed nations of Central Europe and express my deep satisfaction with the fact that between us there is such an impressive and irresistible unanimity of principles." [12].

These too often overlooked efforts, jointly undertaken by Romanians in the Old Kingdom, in Austria-Hungary and in the United State, were, in fact, a key element that ensured America's essential support for Romania's legitimate aspirations at the Paris Peace Conference. The particular dynamics of the Conference are already well-trodden ground for historians, and we shall not dwell on them in this article. Its aftermath, however, certified that President Wilson's trust and support were fully justified and the U.S. had facilitated the emergence of a valuable partner and ally.

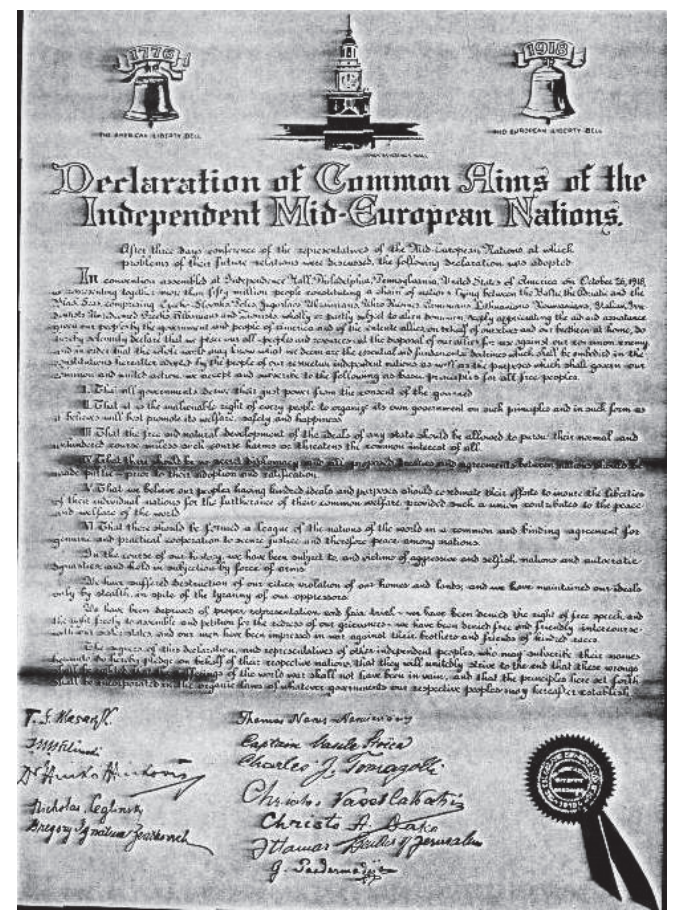

Figure 2. Declaration of Common Aims of the Independent Mid-European Nations signed in Philadelphia, October 26, 1918 
4. Political and economic relations in the interwar period

After the First World War, diplomatic relations between the United States of America and reunited Romania witnessed significant developments, as Romania became one of the most important European countries regarding territory, population, and resources. The Romanian Legation, which operated between 1918 and 1921 at the Shoreham Hotel and the Wardman Park Inn, finally established its official headquarters in the beautiful Beaux-Art building in Sheridan Circle and $23^{\text {rd }}$ Street, where it still stands today. The Embassy was headed by prestigious mission leaders, such as Andrei Popovici, grandson of Civil War hero Gheorghe Pomutz, a well-known U.S. general of Romanian descent. The most important milestones of the Romanian-American relationship during the interwar period concerned the political, economic and cultural dimensions. It is worth mentioning in this respect the famous visit of Queen Marie of Romania to the U.S. in 1926, which included a spectacular parade held in New York (Fig. $3)$. On this occasion, in her message to the American people, the Queen expressed her gratitude for their support: "In all the corners of America there are people who helped of my country. I want to take these people by the hand, look them in the eyes, and tell them wholeheartedly how grateful we are for their sacrifices" [13].

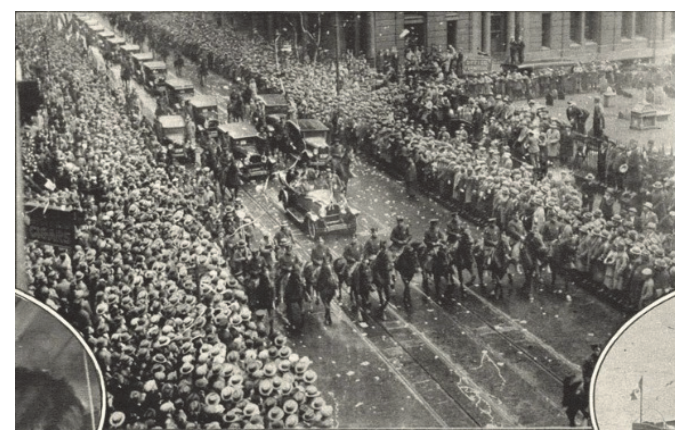

Figure 3. Queen Marie of Romania on Broadway, New York, October 1926

In the same period, the great Romanian historian and politician Nicolae Iorga made a series of visits to American universities, chambers of commerce, Romanian communities and editorial offices of major American publications in New York, Washington, or Chicago. He also met President Herbert Hoover on February 5, 1930.

The economic ties between the two countries intensified. During this period, the first U.S. investments appeared in Romania, especially in the automotive sector, strongly represented (just like today) by the Ford Motor Company, and in the oil industry, as Romania was at that time one of the world's largest oil producers. At the 1939 Universal Exhibition in New York, Romania had several large pavilions that were inaugurated by Sara Roosevelt, the mother of President Franklin D. Roosevelt and the chairman of the patronage committee of the Romanian participation.

The rapid deterioration of the security situation in Europe and the outbreak of the Second World War caught the two countries in an initial phase of neutrality (1939-1941), followed by a phase of hostility (1942-1944), and, after August 1944, by a restoration of relations. The actions of numerous individual Romanians in these turbulent times, such as the good treatment and protection given to U.S. pilots shot down over Romania, clearly show that the general population did not support a conflict with America. An important witness to this was Frank Wisner, the representative of the Office of Strategic Services Operations stationed in Bucharest, who, among other tasks, managed the recovery of downed U.S. Air Force pilots. Wisner was to show himself one of the most clear-eyed observers of evolutions in Eastern Europe after the war, as well as a genuine friend of Romania.

\section{Romanian-American relations after the Second World War}

After the Soviet army forcibly installed the communist regime, Romania followed, for the next two decades after, the direction set by Moscow in its relations with the United States without any significant element of independent foreign policy.

Later, after 1964, when the Romanian legation to Washington D.C. was elevated to the rank of the embassy, and even more after 
1968, bilateral relations expanded, Romania adopting a different attitude and even defying the Soviet line. Remarkable in this respect is the evaluation note The Rumanian Party's Declaration of Independence sent by the National Security Council to President Lyndon B. Johnson. The note referred to a famous declaration of the Romanian Workers' Party from April 1964, which revealed an attempt to escape Soviet tutelage: "This is probably the most far-reaching document of its kind in Eastern Europe since Belgrade severed relations with Moscow. The big difference is, however, that Romania is still inside the bloc [...]. The Romanian doctrine has many difficult points for the Soviet Union to digest [...]. The doctrine could be contagious. And in Moscow's partially immobilized position for dealing with insurgency within its Eastern European ranks, this could well have serious repercussions in other equally fertile parts of European Communist bloc, including Hungary, Poland and Czechoslovakia" [14].

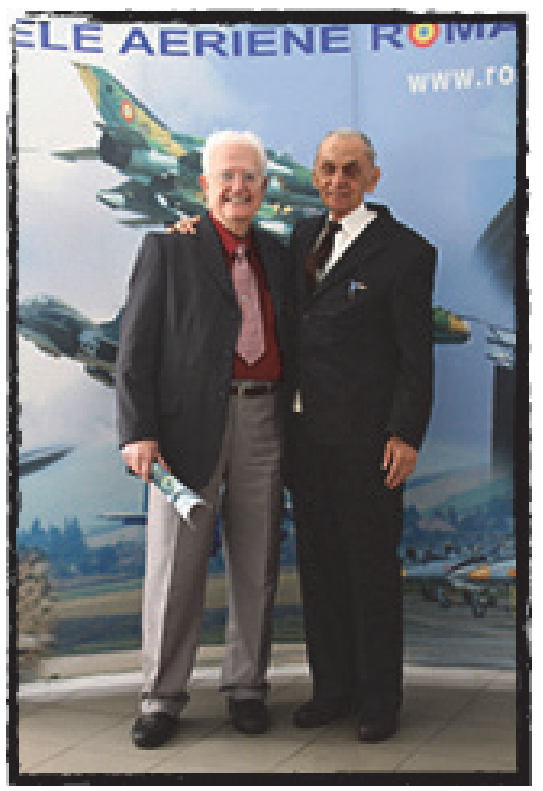

Figure 4. U.S. colonel (ret.) Barrie Davis and Romanian general (ret.) Ion Dobran meet as friends for the first time in 66 years after they fought each other over Romania in the Second World War. Courtesy of http://kogainonfilms.com/Pages/KnightsOfT heSky/Diary.html
This expansion materialized in several ways. Most notable were the two American presidential visits to Bucharest made by Richard Nixon (in August 1969, one year after the Prague Spring - Fig. 5), and by Gerald Ford (in August 1975- Fig. 6).

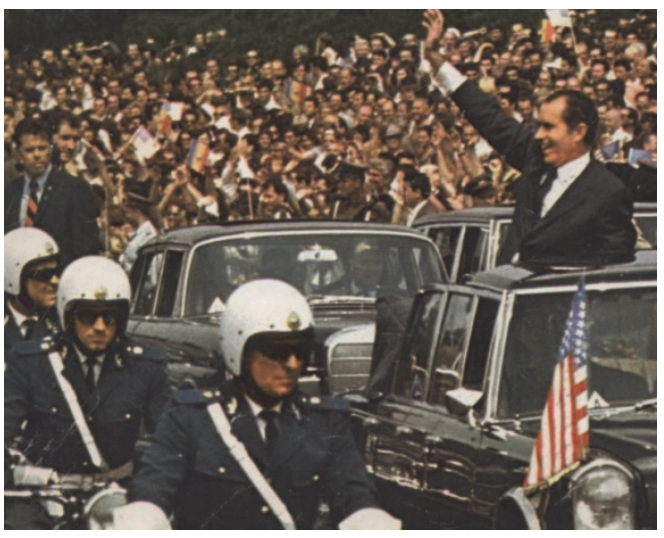

Figure 5. President Richard Nixon in Romania, August 2, 1969 (Source: Agerpres photo archive)

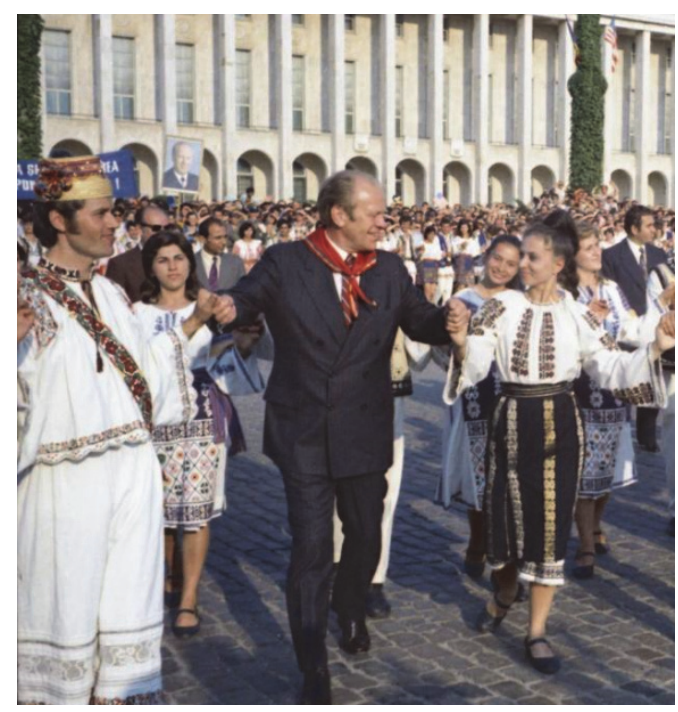

Figure 6. President Gerald Ford in Romania, August 2, 1975, Source: Agerpres photo archive

The visits of U.S. Presidents were followed by several visits of the Romanian Communist leader to the United States. The trade also increased after Romania joined the General Agreement on Tariffs and Trade 
(G.A.T.T.) in 1971, the International Monetary Fund and the International Bank for Reconstruction and Development in 1972, a premiere and an exception for the Eastern Bloc countries.

Last but not least, commercial ties have translated into the adoption of Western technologies in top industry areas. For example, Romania was the only country in the Communist bloc to build a nuclear power plant with Western technology.

The expansion of bilateral relations from the 70s was followed by a brutal deterioration in the 1980s, as the dictatorial tendency of the communist leadership led to a series of abuses and a clear worsening of the human rights situation, which was unacceptable for the Regan administration. In fact, Vice President George H. Bush was the last high-rank U.S. official to visit Bucharest in September 1983. Romanian expatriates in America had an essential contribution in raising the U.S. administration's awareness of the rapidly degrading situation in Romania in the 80s. They were a source of reliable information about the harsh realities of the last decade of the communist dictatorship in Romania, as well as an anchor for the exceptional Romanian-American partnership, which will start to be gradually built after 1989 .

\section{After 1989 - a call back to 1918 and a re-emerging common vision}

In many ways, we can actually speak of a re-building of the Romanian-American partnership after 1989. One could argue that the natural dynamic of the bilateral relationship is one of cooperation, based upon shared values and compatible interests. More importantly, these values and interests are not disparate or temporary alignments, but integral parts of a broad strategic vision, shared by both the U.S. and Romania.

Perhaps unsurprisingly, the emergence of this vision takes us back to the end of World War I and President Wilson, a man who effectively championed many of the things that are today regarded as the core principles of the modern international system. These included not just the self-determination of nations, but also the sovereign equality of states, regardless of size, ensuring the freedom of navigation and the removal of trade barriers. The President also foresaw creating "an association of nations $[\ldots]$ for the purpose of affording mutual guarantees of political independence and territorial integrity to great and small states alike" [15] - what would become, after the war, the League of Nations and, eventually, the UN. For a modern historian, this can easily be seen as a preview of the kind of world that the U.S. would aim to build in the $20^{\text {th }}$ century.

To use an American expression, Romania was an "early adopter" of these ideas. This was not unusual, considering its status as an emerging middle power in post-World War I Europe, facing a broad array of security and economic challenges. In 1919, the future Romanian foreign minister and President of the League of Nations, Nicolae Titulescu, summarized the issue very well: "In addition to victory itself, in addition to the humanitarian Charter that will represent peace in the future, in addition to the guarantees against the possible resumption of war, what small nations owe America above all is the equality under law in a new world and the material means to enforce it" [16]. In a subsequent speech, delivered in front of American journalists in Geneva, in 1925, Titulescu (by then already a cabinet member) further stated: "The fact that America stated countless times that its interest is a Europe that has on its own arrived at a formula of internal [continental] peace, the need to find systems to peacefully settle conflicts among nations, all these things are welcomed warmly and generously by the Romanian people [...]. You [the U.S.] have a concept of international commitments that absolutely coincides with our own. [...] When we receive, across the Ocean a powerful, but gentle reminder that an international commitment must be respected or civilization will cease to exist [...] we feel emboldened in the face of disorder [...] and 
we feel the need to tell you are our brothers in this worldview." [17] In his own expressive manner, Titulescu, articulated the basic premises of a strategic vision that the U.S. and Romania share to this day: the importance of a rules-based interna-tional order, the need for an international peaceful conflict resolution system, as well as effective enforcement mechanisms for it, the key role of a peaceful and united Europe for U.S. and global security. Not coincidentally, both Wilson and Titulescu were criticized as "idealists" in their time. But they were both vindicated in the second half of the $20^{\text {th }}$ century, especially after 1989 . In fact, what seemed to many like an idealist vision in 1918, had a strong underlying current of pragmatism (as one could rightly expect from a U.S. President, or a Romanian foreign minister). The U.S. realized that its own security was inextricably tied to Europe's what we today have come to see as the Transatlantic security space, whose strongest institutional expression is NATO. Furthermore, it understood that, in order to put an end to Europe's destructive cycles of rivalry and conflict, profound geopolitical changes were needed. In 1918, these changes included liberating the Central and Eastern European nations from oppressive and dysfunctional multinational empires (effectively relics of Medieval times) and facilitate the formation of modern states, on a par with those in Western Europe, as well as encouraging peaceful cooperation across the continent. Seventy-one years later, in 1989, one could see remarkable similarities. Once more, the nations of Central and Eastern Europe broke free from oppressive (and dysfunctional) regimes and a heavy-handed hegemon. Once more, they rejoined the Western world as full-fledged members. And, once more, the United States was key in achieving this. The U.S. began to understand in 1918, and realized fully after 1989, that the countries on Europe's Eastern flank could be valuable allies, indispensable for Transatlantic security as a whole. In turn, these states understood (better than many others), that partnership with the U.S. was a cornerstone of their own security and prosperity.

After this detour into hard realism, we turn again to the seeming idealist discourse, in order to identify another part of the common vision shared by the United States and Romania - support for democracy and the rule of law. In his address to Congress requesting a declaration of war Against Germany, on the $2^{\text {nd }}$ of April, 1917, President Wilson stated: "Our object $[\ldots]$ is to vindicate the principles of peace and justice in the life of the world as against selfish and autocratic power and to set up amongst the really free and self-governed peoples of the world such a concert of purpose and of action as will henceforth ensure the observance of those principles. [...] But the right is more precious than peace, and we shall fight for the things which we have always carried nearest our hearts--for democracy, for the right of those who submit to authority to have a voice in their own Governments, for the rights and liberties of small nations, for a universal dominion of right by such a concert of free peoples as shall bring peace and safety to all nations and make the world itself at last free." [18]

The U.S. would enter the global conflict not just to secure a favorable geopolitical order, but also to promote a set of rights and values. As with all of Wilson's seemingly idealistic aspirations, this too had a strong realist dimension, which he himself underlined in his 1917 speech: "A steadfast concert for peace can never be maintained except by a partnership of democratic nations. No autocratic government could be trusted to keep faith within it or observe its covenants. It must be a league of honor, a partnership of opinion" [19]. America would fight for democracy not just because it was the right thing to do, but because it was essential in building the peaceful and secure global system it envisaged. A rules-based international order required "a partnership of opinion”, or, as we put it today, a community of values - words that we use to describe both 
the North-Atlantic Alliance and the EU. The ideas expressed a century ago by President Wilson serve to underline the deep roots of the common strategic vision that the U.S. and Romania share today. Both countries regarded the post-1989 evolutions thorough similar lenses and worked towards the same primary objectives: a Europe whole and free, a robust Transatlantic link, a rules-based international order. In this context, the evolution of the bilateral relation to today's Strategic Partnership and alliance within NATO seems natural. However, this image should not obscure the enormous efforts that led to this outcome. Pursuing NATO and EU membership, developing a close partnership with the U.S., upholding a certain set of values and principles at the international level, were all conscientious and complex decisions assumed by Romania's leaders and citizens. Just as it had done almost a century before, after 1989 Romania chose the path of Western modernity. Even more so then in 1918, the post-1989 option was not just a question of realpolitik, but of choosing the best avenue for the development of the Romanian state and society, politically, economically and culturally. It meant an option for certain values, not just for a certain side. It also meant the full assumption of Romania's obligations as a responsible international actor, as a military ally, as a full-fledged European state, as a democracy.

In addition to its geopolitical impact, U.S. support for Romania's aspirations in 1918 had another significant contribution to the development of a close partnership a century later. It significantly consolidated the genuine sympathy and friendship between the two nations. The positive perception of America among Romanians endured, as we saw, even during some of the most challenging historical times of the $20^{\text {th }}$ Century.

7. The Strategic Partnership: a reflection of shared values, mutual interests, and joint efforts

These shared values and interests found their institutional expression in the current Strategic Partnership between the United States and Romania. The Partnership, initiated in 1997, encompasses a broad scope of cooperation between the two nations, across security and defense, trade and economy, and cultural and people-to-people relations. Its success is proven not just by its longevity, but by its vitality, its exponential growth, and its substantial results. For Romania, these included NATO accession, the development of a vibrant market economy and a robust whole-of-society engagement in support of democratic values and principles. For the U.S., the Partnership has brought a steadfast ally, a valuable trading partner, and a proven friend.

Just over 20 years ago, after an intense campaign towards joining NATO (which would achieve success a few years later) and after the Alliance's 1997 Madrid Summit, on July 11, 1997, Romania welcomed U.S. President Bill Clinton in Bucharest. Acknowledging Romanians' aspiration to freedom and democracy, as well as their spirit, endurance and determination, President Clinton's pledge was clear "our friendship will endure the test of time. As long as you proceed down democracy's road, America will walk by your side." [20]

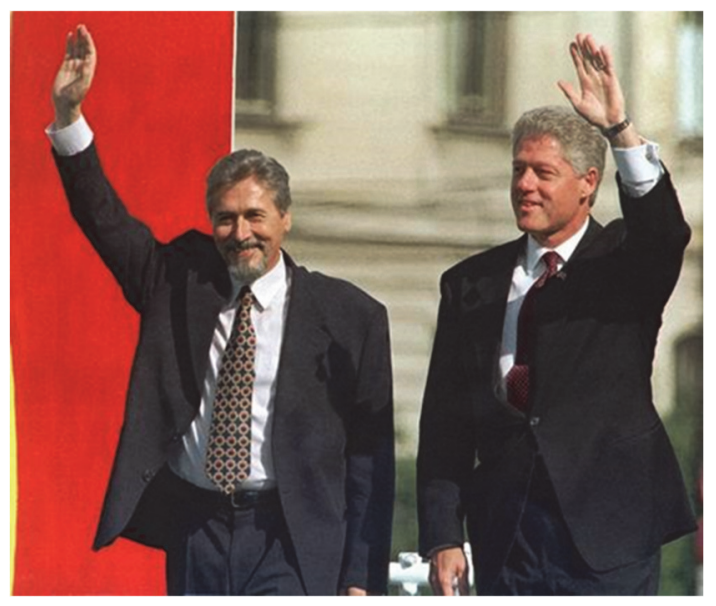

Figure 7. Presidents Bill Clinton and Emil Constantinescu in Bucharest, July 11, 1997 Source: Agerpres photo archive 
This commitment led to both countries agreeing to " (...) establish a strategic partnership between our nations, a partnership important to America because Romania is important to America, important in [its] own right, important as a model in this difficult part of the world. Romania can show the people of this region and, indeed, people throughout the world that there is a better way than fighting and division and repression. It is cooperation and freedom and peace." [21]

The following years demonstrated the transformation of this pragmatic approach into reality, as the United States proceeded to support Romania in essential areas such as security, regional cooperation, economic development and democratic reforms. Romania stayed the course [22], contributed significantly to burden sharing through the support of NATO and U.S. operations in the European theater and Afghanistan, acting as a de facto member even before joining the Alliance. At the beginning of his famous "rainbow speech" to the people of Romania on November 23, 2002, President George W. Bush included a memorable phrase "God is smiling on us today". [23] Those words capture the intensity of the moment, whose meaning, through the invitation to join NATO, was Romania's membership in a community of freedom and democracy.

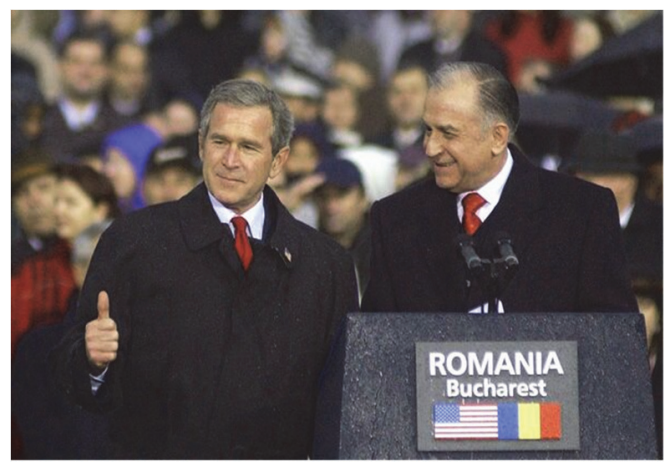

Figure 8. Presidents George W. Bush and Ion Iliescu in Bucharest, November 23, 2002 Source: Agerpres photo archive

On September 13, 2011, Presidents Barack Obama and Traian Băsescu adopted, in Washington D.C., the Joint Declaration on Strategic Partnership for the 21st Century between the United States of America and Romania, a landmark document embodying a strong track record of cooperation across all areas of the Strategic Partnership [24].

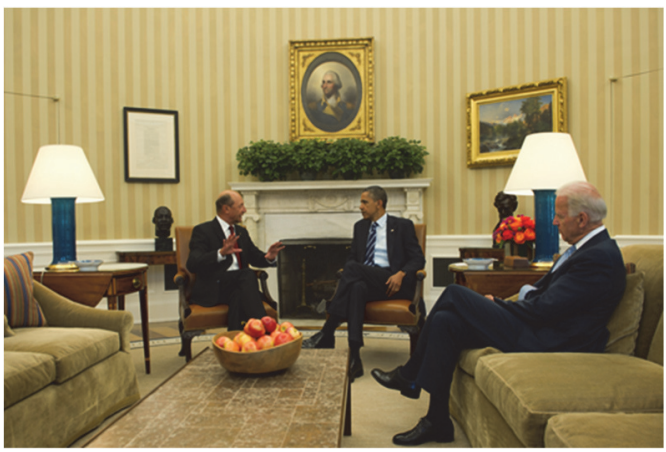

Figure 9. Presidents Barack Obama and Traian Basescu, together with Vice-President Joe Biden at the White House, September 13, 2011 (Source: White House photo archive)

On June 9, 2017, current U.S. President Donald Trump acknowledged the scope and potential of the Strategic Partnership and restated the U.S. commitment to its further development: "Today we especially reaffirm and celebrate our strategic partnership that began more than 20 years ago. That partnership covers many dimensions, including economic, military, and cultural ties. And today we are making those ties even stronger." [25]

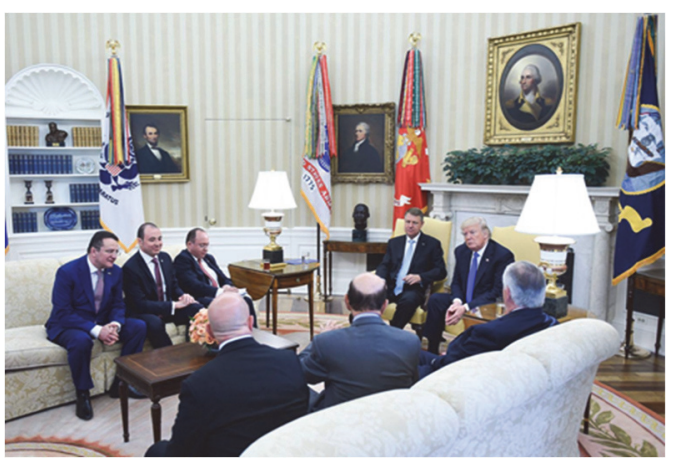

Figure 10. Presidents Donald Trump and Klaus Iohannis at the White House, June 9, 2017 (Source: White House photo archive) 
This series of presidential quotes is, of course, not just an exercise in political eloquence - it highlights the acknowledgment of the Strategic Partnership's importance for both countries as well as the bipartisan support for its development.

The political will of the two nations, expressed at the highest level, gave over the years an impetus to pragmatic cooperation. A yearly strategic dialogue focuses on exploring ideas and concrete projects in line with the political framework set in the Joint Declaration on Strategic Partnership. Such concrete projects were reflected in the Joint Statement on the Implementation of the Joint Declaration on the Strategic Partnership for the 21st Century between Romania and the United States of America, adopted in September 2016 on the occasion of the fifth annual strategic dialogue [26]. Security and defense areas have formed the basis of this dialogue and cooperation and developed in a coherent and constant foundation, codified in legally-binding documents.

Thus, the Defense Cooperation Agreement of 2005 provided the framework for the consolidation of Romania's as well as of the region's security and stability, by increasing the cooperation of the armed forces of both countries through the U.S. forces presence in Romania and prepositioning of equipment across significant facilities in key locations [27]. Notably, such facilities include the Mihail Kogalniceanu Airbase, an important hub of transit to and from Afghanistan, and a major area of joint defense efforts and burden sharing. The airbase also hosts the U.S. Black Sea Rotational Force as well as other U.S. units that give proof to U.S. engagement to this strategic area.

Furthermore, the Ballistic Missile Defense Agreement of 2011 [28] set the framework for a major strategic joint project of the two countries, the deployment of the U.S. Aegis Ashore missile defense facility in the Deveselu Military Base, as part of the development of the U.S. European Phased Adaptive Approach on Missile Defense. The agreement enjoyed broad political and public support, being ratified by the Parliament of Romania almost unanimously. Subsequently, command of control of the facility was transferred to NATO at the Alliance 2016 Warsaw Summit, making possible the declaration of the initial operational capability of the NATO Ballistic Missile Defense [29].

This joint project is illustrative of the substantial contribution that U.S.-Romania bilateral cooperation can bring to the overall security of the Alliance. This recalls the reasoning that both Wilson and Titulescu envisaged a century ago. The value of the partnership was twofold: not just in what the two countries could do for each other, but in what they could accomplish together to advance regional and global shared goals.

A key issue in any alliance and NATO is no exception to this is, of course, fair burdensharing. NATO members have acknowledged it and committed to addressing it, most famously through the Defense Investment Pledge (the well-known 2\% of GDP goal) adopted at the 2014 Wales Summit. Romania has been a strong supporter of this pledged increase in European allies' capabilities. Indeed, in 2017, the rate of growth for Romanian defense expenditure was among the highest in the world, with almost $40 \%$ of that budget going towards acquiring new capabilities. It is worth noting that these new capabilities, such as the Patriot missile system, the high mobility rocket artillery systems, or the F-16 multirole aircraft also led to more interoperability with the U.S. and Allied forces.

The most important thing to underline, when discussing the issue of burden sharing is that, in Romania's case, the driving force was not an external one. The decision to increase investments and develop the national defense capabilities was firmly grounded in the national interest and is a logical and necessary 
response to the current security dynamics. Once again Romania stands out as a valuable partner because its own interests and priorities naturally align with those of the U.S. As a medium-sized European state, Romania also understands the value of functional alliances and the need to actively invest in them.

This includes supporting one's allies where it matters most: on the battlefield. Since 2001, over 30, 000 Romanian soldiers served in theaters such as Afghanistan, Irak, and Kosovo. Currently, in Afghanistan, Romania has the fourth largest troop contingent among NATO Allies, as part of the Resolute Support Mission [30]. Romania is an active contributor to the global fight against terrorism, supports the U.S.-led Coalition against ISIL, and provides essential training to Iraqi armed forces.

In light of Romania's strong commitment and concrete actions towards genuine burdensharing in NATO, it was not coincidental that President Trump first publicly expressed U.S. commitment to Article V of the Washington Treaty in the joint press conference with the President of Romania on June 9, 2017. [31]

As the security and defense partnership matured and consolidated, conditions were created for an exponential expansion of the U.S.-Romania economic relationship. Here, too, Romania profiles itself as a logical choice for U.S. companies. It is the EU's seventh largest country, strategically positioned at the crossroads of all major commercial and energy routes in the region and benefitting from the largest and deepest port at the Black Sea, Constanța. As an entry point to the EU's common economic space, or regional hub for Central and Eastern Europe, the Balkans, the Greater Middle East, the Caucasus and Central Asia, its competitive advantages are numerous. Of course, these aspects have not gone unnoticed by U.S. firms, and this is reflected in the constant growth of both the bilateral trade and investment volume (the peculiarity of the U.S. case is that the investors are some of the largest multinational companies in the world and quite a number of projects are carried out by European subsidiaries, a fact that leads to investments being classified under a different country of origin). [32]

The Romanian economy's diversity and level of development now allows for complex, long-term investment strategies that include modern, competitive industries and the research and development sector. There are areas, such as the automotive or the petrochemical industries, where Romania brings proven experience and expertise. Alongside these, new fields such as the IT sector have reached a level of excellence that allows for cooperation with top U.S. (and global) companies. As Silicon Valley hosts a growing community of Romanian experts and developers, one must keep in mind not just the economic rationale, but also the strategic dimension of this field. Cybersecurity cooperation, both on a bilateral basis and within NATO, is in itself an important element of the Strategic Partnership.

The energy field, perhaps the ultimate example of the strategic economic sector, is one of Romania's main strengths. It is the biggest producer of oil and natural gas in the region and one of the strongest advocates of source diversification and interconnectivity in the EU. European countries' economic independence from actors that leverage energy as a political weapon is a key concern in today's Euro-Atlantic security environment. By virtue of its position, resources and expertise, Romania is well positioned to be part of the solution.

\section{Conclusions and perspectives}

The current geopolitical context, a century after the 1918 Great Union, only serves to underline both the relevance and the potential of the U.S.-Romania Strategic Partnership. As revisionist powers challenge the very foundations of the international order and breach its core norms and principles, it 
becomes even more important to uphold the key tenets of international law, the respect for states' sovereignty and internationally recognized borders, the freedom to make one's own foreign policy choices and reject spheres of influence.

Bearing in mind both historical evolutions and current context, we can draw a set of conclusions about the state and the perspectives of the Strategic Partnership. First, and most obvious, is that the partnership with the U.S. is and will remain an essential pillar of Romania's strategic policy. Second is that the Partnership is firmly anchored in shared long-term strategic interests, a common set of values, as well as genuine affinity and friendship between the two peoples. This means it is not intrinsically tied to a narrow historical moment, as its success and evolution over more than two decades of significant geopolitical shifts have proven. Third, the Partnership has shown itself to be a "living", dynamic framework, constantly expanding and adapting. Its development in relatively new areas, such as energy and cyber security or hybrid threats, demonstrates its adaptability and forward-looking nature. Cooperation in fields such as education, research and people-to-people relations is, in fact, an investment in the future of the Partnership. Fourth, the scope and depth of the Partnership, coupled with a remarkable number of concrete results, underscore the bilateral compatibility and mutual benefits for both the US and Romania.

This (deservedly) optimistic outlook is by no means an invitation to complacency. As a matter of fact, the Strategic-Partnership with the U.S. provides Romania with a key platform for articulating and promoting its own strategic vision in its immediate neighborhood, as well as in the broader EuroAtlantic space. In the greater Black Sea area, the U.S. is both an irreplaceable strategic balancer for an increasingly assertive and aggressive Russian Federation, and an essential factor for promoting a future paradigm focused more on cooperation rather than division. Romania's actions to increase its own capabilities and to encourage regional cooperation formulas must always be complemented by efforts to ensure and support a substantial U.S. presence on NATO's Eastern Flank.

Both countries (relative to their respective sizes and locations, of course) are essential stakeholders in the integrated security of the Euro-Atlantic area. As such, a successful, active and capable NATO is a top common interest of the U.S. and Romania. Effective Euro-Atlantic security is dependent on a strong Transatlantic link, going beyond the collective defense guarantees provided by the Washington Treaty. As a member state of both NATO and the EU, Romania is well positioned to advance ever closer cooperation across the Atlantic.

In the current environment of hybrid aggression, negative propaganda and attempts to undermine international laws and democratic principles, the common values foundation of the U.S.-Romania Strategic Partnership becomes even more important. We must stand together not just in defense of each other's people, territories and sovereignty, but also in defense of human freedoms, democracy and the rule of law.

Appropriate answers to these current challenges require allied unity, political commitment and strategic vision. We must remember that the events of 1918 were by no means pre-ordained, but the result of intense efforts, foresight and courageous decisions, on behalf of political elites and citizens alike. 2018 requires nothing less.

\section{References}

1. https://www.archives.gov/historicaldocs $/$ todays-doc/?dod-date $=108$

2. Victor Mamatey, The United States and East Central Europe. 1914-1918. A Study in Wilsonian Diplomacy and Propaganda, 
edited by Princeton University Press, Princeton, New Jersey, 1957, p. 121

3. Ibidem, p. 129

4. Ibidem, p. 250

5. Ibidem, p. 378

6. Gelu Neamţu, In America for the Union

of Transilvania with Romania, (published in the Romanian language - In America pentru unirea Transilvaniei cu România, Dageron Impex, 1997, p. 82

7. Mamatey, op.cit, pp. 123-126

8. $\quad$ Neamţu, op.cit., pp. 86-89

9. Mamatey, op.cit. p. 376

10. Neamţu, op.cit., p. 91

11. Ibidem, pp. 94-102

12. The New York Times, LXVII, nr. 22

202, November 7th, 1918, p. 11, col 1. Cf. 27 oct. 1918

13. Adevărul, Year 39, no. 13146, October $24^{\text {th }}, 1926$

14. Declassified E.O. 12958, Sec. 3.5, NSC Memo 1/30/95, State Dept. Guidelines, Mai 1,1964

15. President Woodrow Wilson's Fourteen Points, Avalon Project, Yale Law School, http://avalon.law.yale.edu/20th_century/wils on14.asp

16. George G. Potra, Nicolae Titulescu în Statele Unite ale Americii şi Canada. Repere ale unui itinerar politico-diplomatic, Romanian-American Magazine, January 2012, pp. 150

17. Potra, op. cit, pp.152-153

18. Woodrow Wilson, War Messages, 65th Cong., 1st Sess. Senate Doc. No. 5, Serial No. 7264, Washington, D.C., 1917, pp. 3-4

19. Ibidem, pp. 7

20. William J. Clinton, XLII President of the United States: 1993 - 2001, Remarks to the Citizens of Bucharest, Romania, July 11, 1997 ,

http://www.presidency.ucsb.edu/ws/?pid=54 402

21. Ibidem.

22. Ibidem

23. George W. Bush, XLIII President of the United States: 2001 -2009, Remarks to the
People of Romania in Bucharest, November 23, 2002, http://www.presidency.ucsb.edu/ws/index.ph p?pid $=73347 \&$ st $=$ bucharest\&st $1=$

24. U.S. Department of State, Joint Declaration on Strategic Partnership for the 21st Century Between the United States of America and Romania, September 13, 2011, https://2009-

2017.state.gov/p/eur/rls/or/172241.htm

25. Donald J. Trump, XLV President of the United States: 2017 - present, The President's News Conference With President Klaus Iohannis of Romania, June 9, 2017, http://www.presidency.ucsb.edu/ws/index.ph p?pid=126349\&st=romania\&st $1=$

26. Joint Statement on the Implementation of the Joint Declaration on the Strategic Partnership for the 21st Century Between Romania and the United States of America, https://2009-2017.state.gov/r/pa/prs/ps/2016 /09/262495.htm

27. Defense Cooperation Agreement,

28. https://dpap.mapn.ro/app/webroot/fileslib /upload/files/Cooperare\%20militara\%20\%20legi/Legea_268-2006.pdf

29. Ballistic Missile Defense Agreement, http://www.mae.ro/sites/default/files/file/trat ate/2011.09_scut_en.pdf

30. Warsaw Summit Communiqué, issued by the Heads of State and Government participating in the meeting of the North Atlantic Council in Warsaw 8-9 July 2016, paragraph 57,

https://www.nato.int/cps/en/natohq/official_t exts_133169.htm

31. Resolute Support Mission (RSM): Key

Facts and Figures,

https://www.nato.int/nato_static_fl2014/asset s/pdf/pdf_2018_04/20180425_2018-04-

RSM-Placemat.pdf

32. Donald J. Trump, op.cit.

33. Banca Naţională a României, Investițiile Străine Directe în România în anul 2016, p. 13, http://bnr.ro/DocumentInformation.

aspx ?idInfoClass $=9403$ \&idDocument $=26094$ \&directLink $=$ 